\title{
Farmers' Goals and Efficiency in Small-Scale Maize Production: The Case of Eastern Cape Province of South Africa
}

\author{
Douglas Kibirige $^{1}$, Ajuruchukwu Obi ${ }^{2}$, Micah Bheki. Masuku ${ }^{1}$, Ajay Shankar Singh ${ }^{1}$ \\ ${ }^{1}$ Department of Agricultural Economics and Management, Faculty of Agriculture, University of Swaziland, Luyengo, Swaziland \\ ${ }^{2}$ Department of Agricultural Economics and Extension, University of Fort Hare, Alice-Eastern Cape, South Africa
}

\section{Email address:}

kibirige@uniswa.sz (D. Kibirige), aobi@ufh.ac.za (A. Obi), mbmasuku@uniswa.sz (M. B. Masuku), asingh@uniswa.sz (A. S. Singh)

\section{To cite this article:}

Douglas Kibirige, Ajuruchukwu Obi, Micah Bheki. Masuku, Ajay Shankar Singh. Farmers' Goals and Efficiency in Small-Scale Maize Production: The Case of Eastern Cape Province of South Africa. Agriculture, Forestry and Fisheries. Vol. 5, No. 5, 2016 , pp. 191-201. doi: $10.11648 /$ j.aff.20160505.18

Received: August 11, 2016; Accepted: August 22, 2016; Published: September 10, 2016

\begin{abstract}
Farmers' goals in complementarity with natural, physical and financial assets are crucial for efficient production and productivity especially for rural development and economic growth. Goals can be defined as aspirations for which a person has decided to undertake for improved well-being. This article examined correlates of farmers' production efficiency, and their goals and other farmer/farm characteristics. The study was carried out at Qamata and Tyefu irrigation scheme in the Eastern Cape Province of South Africa, respectively. The study involved about 108 of farmers who were interviewed as source of primary data. This article assumes that farmers' goals have a greater impact on their production efficiency. The principal component analysis was employed to establish generalized perceived farmers' goals. Established principal component coefficients were regressed with generated production efficiency scores. A stochastic production frontier analysis was employed to generate the efficiency scores. Generated perceived principal component of farmers' goals included selfexpression (Farm status), business (profit) related goals, social (internal and external network and rules) related goals and independence goals (self-reliance). On average, smallholder farmers were technically inefficient in maize production with a score of about $44 \%$. Farm and farmers' characteristics found to be significantly related to technical efficiency included household size (at $5 \%$ level of significance), years spent in school (at $5 \%$ level of significance), access to training on agronomy (at 5\% level), crop incomes (at $5 \%$ level), and government social grants (at 1\% level of significance). The perceived farmers' goal found to have a positive and significant impact on technical efficiency was farm status at $10 \%$ level, while farmers' goal related to business (profit maximization) had a negative relationship with technical efficiency at $5 \%$ level of significance. This study recommends that all stakeholders in smallholder agricultural sector should participate in planning and implementing policies that match farmers' goals and aspiration, and farmers' improved formal education and access to farm loans, without changing the existing technology.
\end{abstract}

Keywords: Farmers' Goals, farmers, Technical Efficiency, Factor Analysis, Maize Output

\section{Introduction}

Availability of physical assets like land and water without proper management, organisation and co-ordination is believed to be non-productive (Padilla-Fernandez and Nuthall, 2001). Therefore, there is need to set goals and objectives in order to utilize and manage such assets more optimally and efficiently. According to Gasson (1973), farmers express values through implementing a range of farming goals. Goals can be defined as aspirations for which an individual has decided to undertake for improved wellbeing (Padilla-Fernandez and Nuthall, 2001). The purpose and direction to decision-making and performance of the farm depend on the set goals (Maskey et al., 2010), and for the farmer to achieve his/her goals there should be minimised management gaps. Fair weather and Keating (1994) indicated that farmer's goals are known to be related to their styles of 
management. Moreover, management and decision-making among smallholder farmers are based on the values and attitude of a given farmer and society (Vimalra et al., 2012). Goals of the smallholder farmer are not limited to maximising profits, but also to fulfil their beliefs, values, cultural and other sociological endeavours (Harwood, 1979).

In their publication, Eagly and Chaiken (1993) reported that farmer's goals have been used to predict their behaviour. It is therefore only possible to understand why people act the way they do by understanding their behaviours and their value-systems. Identification of farmers' goals may be reflected in their needs, and thus, many international development agencies use the Quality Assessment Framework (QAF) to collect the relevant information related to farmers' needs (FAO, 2011). Organizations like the International Organization for Migration (IOM) and the World Food Programme (WFP) make use of needs assessment to plan and implement emergency programmes during disasters (WFP, 2005). However, most farmers' needs assessments carried by WFP dwell much on increased food output and accumulation of household income or assets with less emphasis on the importance of farmers' social-values and independence goals related to agricultural production.

Literature dated back to the 1960 s and 1970 s reported that measurement of farmers' operations was mainly based on a single-objective decision models, such as profit maximization and the expected utility models (Lichtenstein and Slovic, 1973). However, the approach was criticized by Baumol (1965) for being unrealistic. Baumol (1965) urged that individual goals may not only rely on a single-objective of profits maximization but rather strive to attain satisfactory levels of different objectives like food security, prestige, sense of belonging in a community and independence. Several studies have attempted to measure farmers goals using different approaches like paired comparisons, magnitude estimation, and multidimensional structures (Van Kooten et al., 1986, Padilla- Fernandez and Nuthall, 2001). Some of the common goal statements used in analysis included growth goals, risks, personal goals, farm business and family goals, quality of life goals, and profit goals. These goals are thought to be influenced by individual characteristics like age, education, farming experience, and household incomes, and farm characteristics such as, farm size, access to irrigation water, and other agricultural inputs (Van Kooten et al., 1986; Padilla-Fernandez and Nuthall, 2001). Van Kooten et al. (1986) they indicated that measuring of farmers' goals is important for predicting the economic behaviour and multiple goals can be incorporated into farm simulation models to support farmers in making well-guided decisions.

Farmers' goals are sometimes referred to as aspirations individuals strive to achieve to maximise utility (Obi, 2012). In essence, a goal can be defined as the end, and the method of achieving a goal as means. A farmers' goal of being recognised as the top producer of a given product may act as means to achieve higher goals such as accumulation of wealth. Normally, farmer's values define their goals and the goals define the limits and means of attaining a desired endpoint or performance. Padilla-Fernandez and Nuthall (2001) indicate that most studies carried out to measure farmers' success are limit to profit maximisation with less concentration on other intrinsic goals. Limiting of farmers' goals or success to profit maximisation may lead to condemnation or misjudging of rural farmers' poor adoption of new technologies and undermining rural development programmes. Therefore, this study explore more inclusive farmers' goals and their relationship with farmers' characteristics and technical efficiency to generate more knowledge aimed at understanding why rural communities are persistently engaged in small-scale farming despite their low output.

\section{Methodology}

\subsection{Field Methods}

This study was purposively carried out at Qamata and Tyefu irrigation schemes located in the Eastern Cape Province of South Africa because farmers utilizing the schemes are still battling with high poverty level despite the availability of these economically viable facilities. Further, maize crop was chosen because it is regarded as a staple food, animal feed and source of incomes among households in Qamata and Tyefu area. The study used primary survey data which was collected through administering structured questions and physical observations. Farm/farmer characteristics, farm production and market related data was collected. Using a 4 point Likert scale, respondents were asked to indicate their level of agreement in response to the 21 farmers' goal attitudinal statements, where "1" being strongly disagreed and "4" being strongly agree. These farmers' goal attitudinal statements used in this study were adapted from Padilla-Fernandez and Nuthall (2001) and were redesigned to suit the research. Sixty four and 44 smallholder farmers were interviewed in Qamata and Tyefu communities, respectively, making a total sample of 108 respondents.

\subsection{Analytical Frame Work}

Estimating the Principal Components for the Farmers' Goals and Behaviours

In order to achieve the objective of estimating the principal component that defines the perceived farmers' goals in the study, the factor analysis method was employed. The factor analysis reduces the large number of variables (i.e. farmers' goals/attitudinal statements) to a smaller set of new composite factors (WIDCORP, 2008; Kisaka-Lwayo and Obi, 2012). This process also ensures limited loss of information contained in the large number of attitudinal statements. The underlying factors that explain variance among the farmers' goals or behavioural attitudinal statements were extracted using the factor analysis approach. The extracted factors were then clustered around related attributes such as farmer's goals and behavioural attitudes towards farming. Another reason for using the Principal 
Components Analysis (PCA) is its ability to yield convincing results (Padilla-Fernandez and Nuthall, 2001; Rao, 1964 cited by Kisaka-Lwayo and Obi, 2012).

The variable to be retained in the model had to satisfy the condition that, the coefficients of variables should be equal to eigen values that are greater than one. Thus, such factor explains more variance than any of the original set of variables. To ensure greater factoring ability and sampling adequacy, the Kaiser-Meyer-Oklin (KMO) and the Bartlett's Test of Sphericity tests were used (WIDCORP, 2008). According to WIDCORP (2008), the tests are part of the minimum requirements needed before the data set qualifies for PCA. The KMO uses partial correlations to identify the correlations between pairs of variables, and the recommended minimum value of KMO is 0.6 . The Bartlett's test of sphericity verifies the suitability of data for PCA by either accepting or rejecting the hypothesis based on the relationship between the correlation matrix and identity matrix.

Following Kisaka-Lwayo and Obi (2012), the principal component (PC) of a given dataset of $\mathrm{P}$ numeric variables can be presented mathematically as:

$$
\mathrm{PC}_{\mathrm{n}}=\mathrm{f}\left(\mathrm{a}_{\mathrm{ni}} \mathrm{X}_{\mathrm{i}}, \ldots \ldots \ldots \ldots \ldots \mathrm{a}_{1 \mathrm{j}} X_{\mathrm{j}}\right)
$$

Where $P C$ is the principal component, $\mathrm{n}$ represents a number greater than one. The $P C$ can take different forms of measurement and these include continuous variables, quantity of related products of values that makeup a component, and weighted values or generated values from the component loading. $a_{1 j}$ is the regression coefficient for the $j^{\text {th }}$ variable and it is known as the eigenvector of the covariance matrix between variables. $X_{j}$ is the value of the $j^{\text {th }}$ variable. Explicitly the equation can be written as:

$$
P C_{1}=a_{11} X_{1}+a_{12} X_{2}+\ldots . . a_{1 j} X_{j}
$$

Where $P C_{1}=$ the first principal component. $X_{1}$ and $X_{2}$ are the first and second independent variables of $P C_{l}$ in the linear additive model needed to derive the principal component, and the $a_{11}$ and $a_{12}$ are coefficient (component loadings) associated with the $X_{1}$ and $X_{2}$ variables. Thus, if the study considers multiple principal components, a series of these additive linear combinations of component loadings and variable values can be presented as:

$$
\begin{gathered}
\mathrm{PC}_{1}=\mathrm{a}_{11} \mathrm{X}_{1}+\mathrm{a}_{12} \mathrm{X}_{2}+\ldots \ldots .+\mathrm{a}_{1 \mathrm{j}} \mathrm{X}_{\mathrm{j}} \\
\mathrm{PC}_{2}=\mathrm{a}_{21} \mathrm{X}_{1}+\mathrm{a}_{22} \mathrm{X}_{2}+\ldots \ldots . .+\mathrm{a}_{2 \mathrm{j}} \mathrm{X}_{\mathrm{j}} \\
\ldots \ldots \\
\ldots \ldots \\
\mathrm{PC}_{\mathrm{n}}=\mathrm{a}_{\mathrm{n} 1} \mathrm{X}_{1}+\mathrm{a}_{\mathrm{n} 2} \mathrm{X}_{2}+\ldots \ldots .+\mathrm{a}_{\mathrm{nj}} \mathrm{X}_{\mathrm{j}}
\end{gathered}
$$

Where;

$n=1 \ldots .5$

$j=1 \ldots .45$

$a_{n 1} \ldots . . a_{n j}=$ the component loading

$X_{I} \ldots X_{j}=$ the farmers' goals/behavioural attitudes towards farming

\subsection{Relationship Between Perceived Farmers' Goal and Farmer Characteristics}

The impact of socioeconomic characteristics on perceived farmer's goals was estimated using factor analysis and multivariate regression analysis. The multivariate regression analysis used standard factor scores generated after factor analysis was performed, and these scores were regressed on farmers' socioeconomic characteristics. Thus:

$$
\begin{gathered}
\mathrm{FS}_{\mathrm{ij}}=\beta_{0}+\beta_{1} \text { AGE }+\beta_{2} \text { EDUC }+\beta_{3} \text { EXPE }+\beta_{4} \text { LANDSIZE }+ \\
\beta_{5} \text { CROPINC }+\beta_{6} \text { LIVSINC }+\beta_{7} \text { RMSGP }+\beta_{8} \text { SOURWAT }+ \\
\beta_{9} \text { LOCIRR }+\mathrm{e}
\end{gathered}
$$

Where FSij (dependent variable) = generated regression factor analysis scores, $\beta=$ coefficient parameters to be measured, e $=$ error term, explanatory variable include $A G E$ $=$ age of the farmer (years), $E D U C=$ education level of the farmer (years), $E X P E=$ farming experience (years) of the farmer, $L A N D S I Z E=$ size of land owned (hectares), CROPINC $=$ incomes generated from crop sales (Rand), LIVSINC $=$ Livestock incomes (Rand), RMSGP = remittances, social grants and pension amount received by the farm household (Rand), SOURWAT = Source of water for crop production (Rain, tap, dam, river, or spring), LOCIRR = location of the irrigation scheme

\subsection{Stochastic Frontier Analysis}

There are two most common approaches used in estimating efficiencies levels using the stochastic frontier model and these include "One step" and "Two-step" stochastic frontier approaches (Battese and Coelli, 1995; Wang and Schmidt, 2002 and Phillips, 2012). The latter is reported to ignore the exogenous variables which also contribute to the inefficiency of a firm. A "Two step" method is thought to generate biased results due to misspecification of the model in the first step while the "One-step" method is preferred because it assumes a relationship between the exogenous variables and inefficiency and results in a relatively accurate unbiased efficiency results (Battese and Coelli, 1995; Wang and Schmidt, 2002; Phillips, 2012; Heimeshoff et al., 2013). The Stochastic Frontier Analysis was also employed to estimate the technical efficiency of smallholder farmers for maize enterprise. Results were used to establish resource use efficiency of farmers as a platform to suggest the best enterprise to capitalize on for a more efficient, profitable and sustainable farming business among smallholder irrigation schemes in the Eastern Cape Province. Following Battese (1992) and Rahman (2003), technical efficiency of a given crop production was estimated using a stochastic production frontier, which is specified as:

$$
Y=f\left(X_{i} ; \beta\right)+\ell
$$

Technical efficiency levels are predicted from the stochastic frontier estimation.

$$
Y=A X_{1}^{\alpha_{1}} X_{2}^{\alpha_{2}} \ldots \ldots \ldots X_{n}^{\alpha_{n}} \gamma
$$


The Cobb-Douglas production in equation 4 is loglinearized and fitted in the stochastic frontier analysis. Following Rahman (2003), technical efficiency of maize production is estimated using a stochastic frontier model, and is specified as:

$$
\operatorname{Ln}\left(\mathrm{Y}_{\mathrm{i}}\right)=\beta_{0}+\Sigma_{\mathrm{i}} \beta_{\mathrm{i}} \operatorname{LnX} \mathrm{X}_{\mathrm{ij}}+\left[\mathrm{V}_{\mathrm{i}}-\mathrm{U}_{\mathrm{i}}\right]
$$

Where $\operatorname{Ln} Y_{i}$ is the natural logarithm of output of farmer i, $\operatorname{Ln} X_{i}$ is the logarithm of input variables, $\beta_{i}$ are production coefficients, the $V_{i}$ is a random error, which is associated with random factors not under control of the farmers (like weather, natural disasters, and luck), measurement errors, and other statistical noise, while $U_{i}$ is the technical efficiency measure. Sometimes the error term $\left[V_{i}-U_{i}\right]$ is considered "composite" (Bravo-Ureta and Pinheiro 1997; Rahman, 2003; Chavas et al., 2005). Where $V_{i}$ is a two-sided $(-\infty<$ $\left.V_{i}<\infty\right)$ normally distributed random error $\left[V_{i} \approx N\left(0, \sigma v^{2}\right)\right]$. The term $U_{i}$ is a one-sided $(U i \geq 0)$ efficiency that measures the shortfall in output $Y_{i}$ from its maximum value given by the stochastic frontier $f\left(X_{i} ; \beta_{i}\right)+v$. We assume $U_{i}$ has a half or exponential distribution $\left[U i \approx N\left(0, \sigma u^{2}\right)\right]$. The two components $V_{i}$ and $U_{i}$ are also assumed to be independent of each other. Following Phillips (2012), to verify the suitability of the stochastic frontier model in generating technical inefficiency the ratio $\gamma=\sigma u^{2} / \sigma^{2}$. When the value of (gamma) $\gamma$ is statistically different from zero then this indicates existence of variation in the composite errors term due to inefficiency components, and thus, use of the Stochastic Frontier Analysis is preferred to Ordinary Least Square regression (OLS) model in estimating technical inefficiency (Phillips, 2012). The SFA analysis results presented in Table 5 confirmed the choice of its use in estimating technical inefficiency and not the OLS.

Empirically, log-linear Cobb-Douglas production employed in this study was presented as:

$$
\begin{array}{r}
\operatorname{Ln}\left(Y_{i}\right)=\beta_{0}+\beta_{1} \operatorname{LnX}_{1}+\beta_{2} \operatorname{LnX}_{2}+\beta_{3} \operatorname{LnX} X_{3}+\beta_{4} \operatorname{LnX} X_{4}+\beta_{5} \operatorname{LnX}_{5}+ \\
\beta_{6} \operatorname{LnX}_{6}+\beta_{7} \operatorname{LnX}_{7 . .}+\left[\mathrm{V}_{\mathrm{i}}-\mathrm{U}_{\mathrm{i}}\right]
\end{array}
$$

Where $\mathrm{Y}=$ Amount of crop produced per farm, and $X_{n}$ is a vector of farm inputs/resources employed to produce a given output and these include $X_{1}=$ Land allocated to crop production, $X_{2}=$ Amount of fertilizers used, $X_{3}=$ Amount of seed planted, $X_{4}=$ Amount of pesticide, $X_{5}=$ Amount of herbicides, $X_{6}=$ Total number of times a farmer irrigates his/her plot per season, $X_{7}=$ Total cost for inputs used, $\beta_{0}=$ Constant and $\left[V_{i}-U_{i}\right]=$ "Composite" random error term.

\subsection{Estimating the Impact of Farmers' Goals/Behavioural Attitudinal on Efficiency}

The impact of entrepreneurship on technical efficiency was estimated using a robust Ordinary Least Squares (OLS) because of its characteristics of being unbiased and consistent estimator (McDonald, 2009). The impact of perceived farmers' goals/behaviour on the level of technical efficiency can be determined by establishing the relationship between the estimated average scores derived from Likert scaling of responses for each farmers' goal/behavioural principal component and the computed technical efficiency scores. Following Bravo-Ureta and Rieger (1990), Bravo-Ureta, and Pinheiro (1997) and Padilla-Fernandez and Nuthall (2001), the second step estimates the relationship between the dependent variables (technical efficiency), and farmers goals and the different farm/farmer characteristics. An OLS regression is performed and Durbin-Watson statistic is estimated to determine the extent of autocorrelation problem (Obi and Chisango, 2011). The linear model for individual farmer is estimated as:

$$
\text { T.E }=\beta_{\mathrm{i}} \mathrm{X}_{\mathrm{i}}+\mathrm{e}_{\mathrm{i}}
$$

Where T.E =technical efficiency scores; $X_{i}$ is a vector of explanatory, $\beta_{i}=$ Coefficients and $\mathrm{e}$ is the error term. Empirically, to estimate the relationship between technical efficiency, and farmers' characteristics and perceived farmers' goals, the multiple linear OLS model used generated technical efficiency scores as a dependent variable regressed against the total average scores of farmers' goals that passed the factor analysis test (i.e., the item scores or farmers' goal/behaviour measured using the Likert scale) along with the other explanatory variables. The linear model is estimated

\begin{tabular}{|c|c|c|}
\hline Where Y & $=$ & Technical efficiency scores \\
\hline e & $=$ & Error term \\
\hline$\beta_{0}$ & $=$ & Constant (intercept) \\
\hline$\beta_{1} \ldots \beta_{25}$ & $=$ & Regression coefficients \\
\hline HHSZE & $=$ & Household size \\
\hline AGE & $=$ & Age of the household head \\
\hline LANDSIZE & $=$ & Amount of land owned \\
\hline MJOCUP & $=$ & Major occupation \\
\hline CRPINCOM & $=$ & Crop incomes \\
\hline RMGP & $=$ & Remittances, social grants \& pension \\
\hline SOUCWAT & $=$ & Source of water for crop production \\
\hline IRRLOC & $=$ & Location of the Irrigation Scheme \\
\hline EDUC & $=$ & Years spent in school (Human Capital) \\
\hline EDUCL & $=$ & Education level (categories) \\
\hline EXPE & $=$ & $\begin{array}{l}\text { Farming Experience (years) (Human } \\
\text { Capital) }\end{array}$ \\
\hline $\mathrm{GOAL}_{1}$ & $=$ & $\begin{array}{l}\text { Farm status ( } 1^{\text {st }} \text { principal component for } \\
\text { Farmers'goals) }\end{array}$ \\
\hline $\mathrm{GOAL}_{2}$ & $=$ & $\begin{array}{l}\text { Business ( } 2^{\text {nd }} \text { principal component for } \\
\text { farmers' goals) }\end{array}$ \\
\hline $\mathrm{GOAL}_{3}$ & $=$ & $\begin{array}{l}\text { Social ( } 3^{\text {rd }} \text { principal component for } \\
\text { farmers' goals })\end{array}$ \\
\hline $\mathrm{GOAL}_{4}$ & $=$ & $\begin{array}{l}\text { Independence ( } 4^{\text {th }} \text { principal component } \\
\text { for farmers' goals) }\end{array}$ \\
\hline
\end{tabular}
as shown below for each farmer.

$$
\begin{array}{r}
\mathrm{Y}=\beta_{0}+\beta_{1} \mathrm{HHSZE}+\beta_{2} \mathrm{AGE}+\beta_{3} \text { LANDSIZE }+\beta_{4} \text { MJOCUP } \\
+\beta_{5} \text { CRPINCOM }+\beta_{6} \text { RMGP }+\beta_{7} \text { SOUCWAT }+\beta_{8} \text { IRRLOC }+ \\
\beta_{9} \text { EDUC }+\beta_{10} \text { EXPE }+\beta_{11} \text { EDUCL }+\beta_{12} \text { GOAL }_{1}+\beta_{13} \text { GOAL } \\
+ \\
+\beta_{14} \text { GOAL }_{3} \beta_{15} \text { GOAL }_{4}+\mathrm{e}
\end{array}
$$




\section{Results and Discussion}

\subsection{Characteristics of Farmers}

Table 1 indicates that overall $66 \%$ of farmers were men with an average age of 61 years, and mean household size of 6 persons with the household head having at least obtained some primary school education (6 years in School). Interviewed farmers had farming experience of about 12 years. The major source of water for crop production was river (41\%). Most respondents (89\%) indicated that their major occupation was farming and only $45 \%$ of them received training related to agronomy.

Results presented in Table 1 further indicated that remittance, social grants (child, disability, and elderly) and pension (R3865 received per cropping season) were the major source of income for smallholder farmers. The average crop incomes earned by smallholders was about R2079 per cropping season, and few incomes earned from livestock (R920). This implies that smallholder farmers have a high dependence syndrome and produce less food hardly enough for marketable surplus. Thus, they can be classified as net food buyers and few if any as net sellers.

Table 1. Socioeconomic Characteristics of Smallholder Farmers ( $n=108$ ).

\begin{tabular}{lll}
\hline Characteristics & Description & Percentage \\
\hline Sex of respondent & Male & 66 \\
& Female & 34 \\
Source of water for crop production & Rainfall & 20 \\
& Tape water & 4 \\
& Dam & 35 \\
& River & 41 \\
Major occupation & Farmer & 89 \\
& Self-employed & 6 \\
Whether farmer received training on & Civil servant & 5 \\
agronomy & Yes & 45 \\
& No & 55 \\
Household size & & Average Mean \\
Age of farmer & numbers & 4.65 \\
Education level & years & 61.21 \\
Faming Experience & years & 6.13 \\
Remittances, social grants and pension & Rand (ZAR) & 3864.86 \\
Crop incomes & Rand (ZAR) & 2079.33 \\
Livestock incomes & Rand (ZAR) & 919.64 \\
\hline
\end{tabular}

Source: Survey Data

\subsection{Farmers' Goals and Aspirations Among Smallholders}

The rural household smallholder farmers' goals were estimated using a 4 point Likert scale where "1" being extremely not important and "4" being extremely important. Respondents were asked to indicate the level of importance of 21 attitudinal statements related to farmers' goals. The goals were clustered into four value orientations as defined by Gasson (1973). The four values included intrinsic, expressive, social and instrumental. Farmers scored highly ( $>3.0$ average mean score) on goals related to intrinsic behaviours and social related values. Intrinsic behaviours considered important by farmers included being selfemployment and independent (mean $=3.44, \mathrm{SD}=0.52)$ and practicing farming as a lifestyle $($ mean $=3.64, \mathrm{SD}=0.42)$.

Table 2. Average Item Scores of Farmers' Goals and Aspirations $(n=108)$.

\begin{tabular}{|c|c|c|}
\hline Intrinsic & Mean & SD \\
\hline Self-employed and independent & 3.44 & 0.52 \\
\hline Like farming life & 3.61 & 0.42 \\
\hline Have more leisure time & 2.56 & 0.81 \\
\hline Total average mean score & 3.20 & \\
\hline \multicolumn{3}{|l|}{ Expressive } \\
\hline Be recognised as top producer & 2.64 & 0.93 \\
\hline Be recognised as a leader in the technology adoption & 2.46 & 1.02 \\
\hline Be recognised as a specialist in growing these crop & 2.63 & 0.95 \\
\hline Be recognised as owner of the land & 2.96 & 0.94 \\
\hline Total average mean score & 2.67 & \\
\hline \multicolumn{3}{|l|}{ Social } \\
\hline Involve family in decision-making & 3.17 & 0.91 \\
\hline Leave business for the next generation & 2.87 & 0.80 \\
\hline Provide employment to rural people & 3.08 & 0.92 \\
\hline Belong to farming community & 3.00 & 0.76 \\
\hline Inherited the farm & 3.21 & 0.92 \\
\hline It is part of culture (artefacts and adornment) & 3.14 & 0.62 \\
\hline Contacts with people, transfers of Information & 3.15 & 0.68 \\
\hline Social participation: meetings and rituals & 3.18 & 0.73 \\
\hline Avail time to spend with my family & 2.88 & 0.77 \\
\hline Total average mean score & 3.08 & \\
\hline \multicolumn{3}{|l|}{ Instrumental } \\
\hline Increase standards of living & 2.99 & 0.80 \\
\hline Increase maximum farm income & 3.11 & 0.71 \\
\hline Expand the business & 2.99 & 0.77 \\
\hline Keep debts as low as possible & 3.26 & 0.68 \\
\hline Accumulate wealth & 2.92 & 0.99 \\
\hline Total average mean score & 3.05 & \\
\hline
\end{tabular}

Source: Survey data: Where; SD = Standard deviation

The key social related behaviours of farmers scored highly with mean value greater than three were: involve family in decision-making (mean $=3.17, \mathrm{SD}=0.91$ ); provide employment to rural people (mean $=3.08, \mathrm{SD}=0.92)$; belong to farming community (mean $=3.00, \mathrm{SD}=0.76$ ); inherited the farm (mean $=3.21$, SD $=0.92)$; it is part of culture (artefacts and adornment) (mean $=3.14, \mathrm{SD}=0.62)$; contacts with people and transfer of information (mean = $3.15, \mathrm{SD}=0.68)$; and social participation: meetings and rituals $($ mean $=3.18, \mathrm{SD}=0.73)$. Among the instrumental related behaviour, increasing maximum farm income (mean $=3.11, \mathrm{SD}=0.71$ ) was considered important for interviewed farmers. Based on these results farmers in the selected area mainly farm to satisfy their social demands rather than personal or business related goals. Farmers considered expressive values (Self-esteem) as less important, thus, farmers seem to lack confidence and this may lead to low interest in farming resulting inlow productivity levels of individuals. Low self-esteem, low productivity has resulted in farmers' less interest in expanding their fields, and to the extent of abandoning them. This situation is anticipated to expose rural subsistence farming to stagnant and declining, resulting in high risks of hunger, poverty and high dependence on social grants. 


\subsection{Principal Components for the Perceived Farmers' Goals and Aspirations}

Factor analysis was used to estimate the principal components (related to farmers' goals and attitudes as presented in Table 3. It was worth using this method to condense the 21 goal and attitudinal related statements into fewer well explained principal components. During the analysis, some statements were dropped to achieve better results that correspond with the minimum Kaiser-MeyerOlkin Measure (KMO) of Sampling Adequacy value of 0.60 and the Bartlett's Test of Sphericity. The KMO value for this particular analysis was 0.643 and passed the Bartlett's Test of Sphere with no autocorrelation among variables. Also the Eigen value proportions of the variance for the selecting optimal number of principal components were above the recommended value of 1 . Eleven out of twenty one goal and attitudinal related statements passed the two mandatory tests and were considered in the factor loading statistical measurement stage. The eleven goal and attitudinal statements yielded four principal components that explained $68.52 \%$ of the variation in the explanatory variables. The four principal components are, farm status/expressive (PC1), business (PC2), social (PC3), and independence oriented goals (PC4).

The first principal component (farm status) displays a variation of $25.16 \%$ in the famers' rankings of their goals. The principal component was best described as a farm status, expressive or self-esteem oriented goal. There are six farmers' goal related statements that have estimated coefficients above 0.30 and defined this principal component. Farmers had an interest of being attached to their farm successes. All the four expressive or self-esteem related goals are part of the farmers' goals that explain the first principal component. In this case, the self-esteem or confidence may be of great importance to farmers for better performance as they strive to achieve these goals. Although the principal component was mainly described by the farm status/selfesteem goals, it has some elements of business oriented goals like increase maximum incomes and accumulating wealth.

Table 3. Estimated Principal Components for the Perceived Farmers' Goals and Aspirations.

\begin{tabular}{|c|c|c|c|c|}
\hline & Farm status & Business Oriented & Social Oriented & Independence \\
\hline Proportion of Variation (\%) & 25.16 & 19.70 & 14.07 & 9.60 \\
\hline Eigen value & 2.767 & 2.167 & 1.548 & 1.056 \\
\hline Farmers' Goals and Aspirations & Factor Loadings & $\mathrm{P} C 2$ & $\mathrm{P}_{3}$ & $\mathrm{DCH}$ \\
\hline Self-employed and independent & -0.036 & 0.516 & 0.135 & 0.478 \\
\hline Have more leisure time & -0.070 & -0.143 & 0.552 & 0.697 \\
\hline Be recognized as top producer & 0.768 & -0.352 & 0.208 & 0.044 \\
\hline Be recognized as a specialist in growing these crop & 0.853 & -0.136 & 0.008 & 0.053 \\
\hline Be recognized as owner of the land & 0.405 & -0.323 & -0.546 & 0.185 \\
\hline Contacts with people, and transfers of information & 0.077 & 0.015 & 0.792 & -0.278 \\
\hline Social participation: meetings and rituals & 0.257 & 0.589 & -0.284 & 0.345 \\
\hline Increase standards of living & 0.193 & 0.776 & -0.191 & -0.030 \\
\hline Increase maximum farm income & 0.555 & 0.546 & 0.024 & -0.300 \\
\hline Accumulate wealth & 0.541 & 0.450 & 0.362 & -0.089 \\
\hline \multicolumn{5}{|c|}{ Kaiser-Meyer-Olkin Measure (KMO) of Sampling Adequacy $=0.643$} \\
\hline \multicolumn{5}{|l|}{ Bartlett's Test of Sphericity Approx. Chi-Square $=342.739$} \\
\hline Model significance level $=1 \%$ & & & & \\
\hline
\end{tabular}

Source; Survey data: Note: The bold and underlined factors $>(0.3)$ qualify to constitute a given component. $(n=108)$

The second principal component accounted for $19.70 \%$ of variation in the variables and mainly comprises business and developmental farmers' related goals. These include improved standards of living, increase maximise farm incomes and wealth accumulation. Although smallholder farmers produce low output and less marketable surplus, they still view farming as one of the major sources of livelihood. Farmers at Qamata and Tyefu irrigation scheme areas grow vegetables and maize and sell it within local markets to earn a living. The major vegetables grown for sale include cabbages, spinach, potatoes and carrots, among others. Farmers' business oriented goals can be of great importance in boosting production and increase marketable surplus. Famers' business goals can therefore be incorporated in rural development programmes for improved smallholder incomes and general livelihood.
In addition to wealth accumulation, farming activities are used as media of communication among rural communities and this can be of great importance in accumulating social capital. This principal component can be described as farmers viewing farming as a channel for improved interpersonal relations (seeking utility or satisfaction through social relations) within a given community. The farmers' social oriented goals form the third principal component which accounts for $14.07 \%$ of the variation in the explanatory variables. Farmers' social oriented goals aid the flow of production and market information among themselves. Improved information flow is thought to increase adoption of new technologies and improved access to market information for reduced transaction costs caused by information asymmetry. Thus, rural development programmes can design policies that are directed towards strengthening the social 
oriented goals among the smallholder farmers.

The fourth principal component generated from the farmers' goal statements could be best defined as farmers' independence oriented goal and was explained by $9.60 \%$ of variation in the explanatory variable. Farmers viewed farming as source of self-employment and independence (freedom), and avails more leisure time. More leisure time and freedom avails more opportunities for farmers to participate in social gatherings. The majority of rural population in developing countries engage in smallholder farming as a major source of livelihood and as source of selfemployment. This attribute can be enhanced by promoting smallholder farming as business and source of selfemployment among rural communities.

\subsection{Farmer's Characteristics and Goal Orientations}

Using multiple regression models, the association between the farm/farmers' characteristics and their goals was established. Results indicate significant relationship between the farm/farmers' characteristics and their goals as presented in Table 4. The three regression models related to farmers' goals of farm status, business related, and independence (self-reliance) are all significant at $1 \%$ level, respectively. There was low extent of autocorrelation registered within the regression models since results exhibited a Durbin-Watson statistics greater than 1. The farm status, business and independence goals exhibited an averagely lower goodnessof-fit of the model (low $\mathrm{R}^{2}$ values) or the model explained less about the relationship between the dependence and explanatory variable. According to Kisaka-Lwayo and Obi (2012), the less explanation of the relationship between the dependent and explanatory variable results (low $\mathrm{R}^{2}$ value) is mostly related to discrete choice models.

Table 4. The Farm/Farmers' Characteristics Associated with Farmers' Goalsand Aspirations.

\begin{tabular}{|c|c|c|c|c|c|c|c|c|}
\hline \multirow{3}{*}{ Independent Variables } & \multicolumn{8}{|c|}{ Extracted Components of Farmers' Goals\& Aspirations } \\
\hline & \multicolumn{2}{|c|}{ Farm status } & \multicolumn{2}{|c|}{ Business Oriented } & \multicolumn{2}{|c|}{ Social Oriented } & \multicolumn{2}{|c|}{ Independence } \\
\hline & $\boldsymbol{\beta}$ & p-value & $\boldsymbol{\beta}$ & p-value & $\boldsymbol{\beta}$ & p-value & $\boldsymbol{\beta}$ & p-value \\
\hline Age & -0.010 & 0.267 & 0.003 & 0.755 & 0.020 & $0.091 *$ & 0.015 & 0.151 \\
\hline Education & 0.061 & $0.012 * * *$ & 0.040 & 0.157 & 0.013 & 0.673 & 0.103 & $0.000 * * *$ \\
\hline Farming Experience & -0.013 & 0.112 & 0.010 & 0.317 & -0.007 & 0.493 & 0.009 & 0.309 \\
\hline Land size & -0.215 & $0.028 * *$ & 0.094 & 0.402 & 0.010 & 0.936 & 0.164 & 0.135 \\
\hline Crop incomes & 0.000 & $0.017 * *$ & -0.000 & 0.356 & 0.000 & 0.187 & -0.000 & 0.226 \\
\hline Remittances, social grants, pensions & 0.000 & $0.009 * * *$ & 0.000 & 0.499 & 0.000 & 0.946 & 0.000 & $0.006^{* * *}$ \\
\hline Source of water for crop production & 0.197 & $0.011 * * *$ & 0.206 & $0.021 * *$ & -0.119 & 0.209 & -0.000 & 0.567 \\
\hline Location of irrigation scheme & -0.411 & 0.133 & -0.90 & $0.005 * * *$ & 0.671 & $0.049 * *$ & 0.955 & $0.002 * * *$ \\
\hline (Constant) & 0.001 & 0.999 & -0.186 & 0.841 & -1.848 & $0.065^{*}$ & -3.124 & $0.001 * * *$ \\
\hline $\mathrm{R}^{2}$ adjusted & 0.354 & & 0.131 & & 0.004 & & 0.179 & \\
\hline p-value & $0.000 * * *$ & & $0.006 * * *$ & & 0.411 & & $0.001 * * *$ & \\
\hline Durbin-Watson statistics & 2.153 & & 1.833 & & 1.960 & & 1.460 & \\
\hline
\end{tabular}

Source: Survey data: Where $* * * *, * * *$ represents significance at $1 \%, 5 \%$ and $10 \%$ level of significance, respectively.

Determinants of farmers' farm status goal (self-esteem) include education level, livestock incomes, remittance, grants and pension, and source of water for crop farming with a positive and significant impact on farmer's farm status oriented goal at $1 \%$ level, respectively. Incomes from crops had a positive and significant influence on farm status oriented goal at $5 \%$ level, while land size had a negative and significant impact on the same goal at 5\% level. Thus, increased farm incomes, remittances, social grants and pension, and access to water improves farmer's farm status/self-esteem, while an increase in the amount of land owned reduce farmer's self-esteem.

The second principal component (business oriented goal) has a positive and significant relationship with the source of water for crop production at 5\% level of significance, and a negative and significant relationship with location of the irrigation scheme at $1 \%$ level of significance. Thus, farmers who access dam and river water for crop production are more likely to view farming as an income generating activity. Water is one of the primary agricultural resources needed in farm business especially in semi-arid areas like Qamata and Tyefu, and hence, access to more water increases the farmers' ability to diversify for increased farm output. Increased farm output may result in increased farm incomes, standards of living, and accumulated wealth. Further, the negative relationship between the location of the irrigation scheme and farmers' business oriented goal can be explained as, farmers located at Tyefu irrigation scheme are more likely to view farming as business compared to farmers at Qamata irrigation scheme. Since most interviewed farmers were staying at Qamata, they view farming as not business.

Age of the household head and location of the irrigation schemes were the only farmers' and farm characteristics, respectively, that had a significant impact on farmers' social oriented goal. Both age and location of the irrigation scheme had a positive and significant impact on the social oriented goal at a $10 \%$ and $5 \%$ level, respectively. This means that old aged farmers view farming as a social oriented activity and were mainly located at Qamata irrigation scheme.

Most smallholder farmers located at Qamata irrigation scheme had higher education level and earned more remittances, social grants and pension incomes are more likely to view farming as an activity that avails more freedom than any other related activity (or self-employment). 
Education level, amount of remittances, social grants and pension, and the location of the irrigation scheme had a positive and significant influence on farmer's independence oriented goal. More education may facilitate innovation of time saving farm technologies/methods and adoption of labour saving technologies, which in turn avails more leisure time.

\subsection{Technical Efficiency of Smallholders Using Stochastic Frontier Analysis}

Technical efficiency scores of maize enterprise among smallholder farmers were generated from this estimation and are presented in Table 4. Keeping other factors constant, estimated stochastic frontier production function indicated that amount of land, seed planted, number of irrigations/ha/season and input total costs had a positive and significant influence on maize output at $1 \%$ level, respectively. Thus, a unit increase in land allocated to maize production, amount of seed planted, and number of irrigations/ha/season and purchased farm inputs increases maize output by about 2, 0.4, 1 and 0.3 units, respectively. Amount of pesticides applied on maize crops had a negative and significant impact on maize output at 5\% level. Indicating that an increase in the number of smallholders applying less amounts of pesticide result in a decrease of 0.234 units of maize output. The amount of fertilizers applied had an unexpected negative sign since most studies claim a positive relationship. This is probably because most smallholders were applying inadequate amounts fertilizers leading to low maize outpu.

Table 5. Stochastic Frontier Analysis Results for Maize Enterprise ( $n=108)$.

\begin{tabular}{lllll}
\hline & \multicolumn{1}{l}{ Maize Output (Y)= Dependent Variable } & \\
\hline Independent Variables (in natural logarithm) & Coefficient & S.E & Z- Value & P-value \\
\hline Land under maize farming (ha) & 1.982 & 0.244 & 8.13 & $0.000^{* * *}$ \\
Quantity of seed planted (Kg/ha) & 0.391 & 0.099 & 3.93 & $0.000^{* * *}$ \\
Quantity of fertilizer applied (Kg/ha) & -0.053 & 0.070 & -0.75 & 0.450 \\
Quantity of herbicide applied (L/ha) & 0.095 & 0.153 & 0.62 & 0.536 \\
Quantity of pesticide applied (L/ha) & -0.234 & 0.115 & 2.04 & $0.041^{* *}$ \\
Number irrigations per season/ha & 1.013 & 0.134 & 7.57 & $0.000^{* * *}$ \\
Total costs on maize inputs (Rand) & 0.326 & 0.082 & 3.97 & $0.000^{* * *}$ \\
Constant & 1.078 & 0.484 & 2.23 \\
sigma_v & 0.253 & 0.167 & $0.026^{* *}$ \\
sigma_u & 1.310 & 0.196 & \\
Sigma 2 & 1.780 & 0.447 & \\
lambda & 5.171 & 0.347 & & \\
Log likelihood $=-120.805$ & & & & \\
Prob $>$ chi2 $=0.000^{* * *}$ & & & \\
Wald chi2 (6) $=426.62$ & & & \\
Number of Observations $(\mathrm{n}=105)$ & & & \\
\hline
\end{tabular}

Source: Survey data: Where $* * * * *$ represents significant at $1 \%$ and $5 \%$, respectively

Technical efficiency was obtained by using the estimated parameters from the log-linear Cobb-Douglas Stochastic Frontier Analysis. The minimum estimated efficiency score of smallholder farmers whose production activities were less influenced by direct interference of extension officers and cooperative management is 2.37 percent, the maximum is 88.0 percent and the overall mean was 44.21 percent as shown in Table 6.

Table 6. Range of Technical Efficiency for Maize Enterprise ( $n=108)$.

\begin{tabular}{l|l}
\hline Ranges of Efficiency (\%) & Farmers within the specified category (1st column) (\%) \\
\hline$<20$ & 18 \\
$20-39$ & 48 \\
$40-59$ & 4 \\
$60-79$ & 24 \\
$80-99$ & 6 \\
Total & 100 \\
Minimum individual score $=2.37 \%$ and Maximum individual score $=88.0 \%$ \\
\hline
\end{tabular}

Source: Survey data

The efficiency ranges in percentages are presented in Table 5. Overall, few smallholder farmers $(30 \%)$ growing maize in the study area were technically efficient. Only $6 \%$ of smallholder irrigators were $80 \%$ and above technically efficient while $24 \%$ of them were at least operated between $60 \%$ and $79 \%$ of technical efficiency level. According to the results presented in Table 5, more than half of smallholder irrigators $(70 \%)$ were technically inefficient and operated below $60 \%$ of technical efficiency. Therefore, smallholder irrigators need to step-up their efficiency by $55.79 \%$ for increased maize productivity. 


\subsection{Factors Affecting Farmers' Technical Efficiency}

An Ordinary Least Square linear regression of technical efficiency scores against explanatory variables was estimated. The inefficient effects (explanatory variables) were specified as those related to famers' characteristics and the perceived generated principal components of farmers' goals (average score values). The Durbin-Watson statistic for the regression model was 1.838 signifying limited autocorrelation problems. The F-value indicates that the explanatory variables combined, significantly influence changes in the dependent variable at $1 \%$ level. The technical inefficiency model indicates that socioeconomic characteristics such as household size and farm incomes have a positive impact on technical efficiency, both significant at $5 \%$ level, respectively Cha.

Table 7. Factors affecting farmers' Technical Efficiency.

\begin{tabular}{lllll}
\hline Variables & \multicolumn{3}{l}{ Dependent variable: Technical Efficiency Scores } \\
\hline & Coefficients & Std. Error & t-Values & Significance \\
\hline Household size & 0.019 & 0.010 & 1.960 & $0.053^{* *}$ \\
Age of Farm & -0.002 & 0.003 & -0.778 & 0.438 \\
Amount of land owned & -0.036 & 0.026 & -1.359 & 0.177 \\
Years spent in school & -0.016 & 0.008 & -2.088 & $0.039^{* *}$ \\
Whether received training on agronomy & -0.125 & 0.058 & -2.144 & $0.035^{* *}$ \\
Farm Incomes & 0.000 & 0.000 & 2.297 & $0.024^{* *}$ \\
Remittances and Social grants & -0.000 & 0.000 & -2.647 & $0.010^{* * *}$ \\
GOAL-PC1 (Farm status) & 0.219 & 0.131 & 1.672 & $0.098^{*}$ \\
GOAL-PC2 (Business oriented) & -0.367 & 0.188 & -1.954 & $0.054^{* *}$ \\
GOAL-PC3 (Social oriented) & -0.103 & 0.083 & -1.243 & 0.217 \\
GOAL-PC4 (Independence) & 0.137 & 0.100 & 1.368 & 0.175 \\
(Constant) & 1.173 & 0.355 & 3.301 & $0.001^{* * *}$ \\
R-Squared : 0.204 & & & & \\
F-value: $2.239 * * *$ & & & & \\
Durbin Watson Test: 1.838 & & & \\
\hline
\end{tabular}

Source: Survey data: Where ${ }^{* * *}, * *$ and $*$ represents significance at $1 \%, 5 \%$ and $10 \%$ level of significance, respectively.

In most African rural settings, increased household size means increased farm family labour force. It is thought that an increase in the family size improves production efficiency by availing more family labour for a more equitable labour distribution among farming activities. According to Asiimwe (2009), increased farm family labour may result into a higher concentration of a farmer on more demanding farm tasks and thus improving production efficiency. The findings of this study are consistent with those of Amos (2007) Haji (2007). The positive and significant effect of crop incomes on technical efficiency of maize producers under study may be due to re-investments done through purchase of farm inputs.

Education level in terms of years spent in formal schools by the farmer had a negative and significant affect technical efficiency at $5 \%$ level of significance, respectively. This indicates that education may not be of great importance among maize producers in the study area. Receiving trainings on agronomical practices had a negative and significant impact on farmers' technical efficiency. The negative and significant impact of training on technical efficiency suggests that the majority untrained farmers $(55 \%)$ in agronomy are more likely to be technically inefficient in maize production. Incomes earned from remittance, social grants and pension has a negative and significant impact on the technical efficiency of maize production at $1 \%$ level. This is probably because rural households that receive more social grants tend to reduce their interests in farming as source of livelihood and hence, devoting less farm family labour and energy to cultivate in anticipation of receiving some money from government (Machethe et al., 2004).

Farmers perceiving farm status (self-expression) goals important are more likely to be efficient than those who do not consider such goals as important. Results in Table 7 revealed that these goals have a positive and significant impact on technical efficiency at $10 \%$ level. Thus, farmers' self-expression towards the progress of their farms improves technical efficiency. Farmers in the study areas expressed their positive interest in farming as a prestigious activity of recognition despite the numerous impediments faced like difficulties of accessing farm land and irrigation water. This is greatly believed to positively and significantly impact on their farm production efficiency. Surprisingly, the findings of this study indicate that technically inefficient farmers are more likely to give high importance to farmers' business related goals than the technically efficient farmers. According to results, farmers' business oriented goals had a negative and significant impact on technical efficiency of maize production at $\mathrm{p}<0.05$ level. Padilla-Fernandez and Nuthall (2001) findings are consistent with this study regarding the negative impact of business and social oriented goals on technical efficiency.

\section{Conclusion and Recommendations}

\subsection{Conclusions}

Smallholder farmers in Qamata and Tyefu communities in the Eastern Cape Province of South Africa had an average age of 61 years, at least obtained some primary school education, with farming experience of about 12 years. Water for crop production was mainly obtained from rivers, and they highly depended on average social grants (child, 
disability, and elderly) of R3865 per crop season and average crop incomes of R2079 per crop season as their source of livelihood. Smallholders engaged in farming to achieve:

- Self-satisfaction/independence (intrinsic) goals with the highest total average means score of 3.20, and this goal was determined by farmers' education level $(\mathrm{P}<0.01)$, social grants received $(\mathrm{P}<0.01)$, and location of the irrigation scheme (Qamata) $(\mathrm{P}<0.01)$.

- Increased cohesion within social-groups and adhere to cultural norms (total average mean score of 3.08). This goal was targeted by older farmers $(\mathrm{P}<0.1)$, and mainly located closer to Qamata irrigation scheme $(\mathrm{P}<0.05)$.

- Increased farm incomes at a lesser cost and accumulation of wealth (business) (total average mean score of 3.05). This goal was mainly targeted by farmers who draw water from dams and rivers to irrigate their maize $(\mathrm{P}<0.05)$, especially those located at Tyefu irrigation schemes $(\mathrm{P}<0.01)$.

- A higher farm-status (total average mean score of 2.67). Farmers with higher formal education qualification $(\mathrm{P}<$ $0.01)$, generating more incomes from crops $(\mathrm{p}<0.05)$, livestock $(\mathrm{p}<0.01)$ and social grants $(\mathrm{P}<0.01)$, had access to irrigation water from dams and rivers $(\mathrm{P}<$ $0.01)$, and smaller plots of land $(\mathrm{P}<0.05)$, had more desires to achieve a higher farm-status.

Technically efficient famers in the study area tend to focus on attaining a higher farm status goal $(\mathrm{P}<0.1)$ rather than viewing farming as a business $(\mathrm{P}<0.05)$. Other determinants of technical efficiency of smallholder maize farmers included household size $(\mathrm{P}<0.05)$, education level $(\mathrm{P}<0.05)$, trained in agronomy ( $\mathrm{P}<0.05)$, farm incomes $(\mathrm{P}<0.05)$, and remittances and social grants $(\mathrm{P}<0.01)$. Thus, awarding systems that promote farmers' recognition as top producers, lead adopters of new technologies, specialist in crop production, and owner of farm land play a key role on improving technical efficiency of maize production in the study area.

\subsection{Recommendations}

The findings of this study indicate that most farmers are aged and seem to lack vitality, enthusiasm and flexibility required for efficient farm production. Therefore, rural development policies and programs that target youth engagement in farming should be catalysed through provision of trainings in agronomy, financial assistance in form of start-up capital and availing labour saving and appropriate technologies.

Since farmers' goals as defined in the literature and this study are not things that are amenable to direct policy intervention, they can only be modified indirectly through policy actions that affect their determinants. This means that a number of socio-economic characteristics such as age, sex and education level of household head, farming experience, size of land owned, crop incomes, source of water for irrigation and location of the irrigation scheme that govern the way people perceive reality and respond to them must be the focus of concerted policy actions over the medium to long term.
For improved technical efficiency of maize production among small-scale farmers in the study area, the government, NGOs, CBOs, and private sector should join hands and devise means of availing extension services and trainings mainly focused on agronomy.

The government of South Africa, NGOs, CBOs and other stakeholders promoting improved food security and poverty eradication in rural communities through small-scale agriculture should provide more awards to best performing farmers. This will encourage them to improve on their farmstatus and indirectly boot their technical efficiency. Thus, policy-makers need to incorporate farmer's goals related to farm-status (self-expression) for increased production, food security and poverty eradication.

\section{References}

[1] Amos, T. T. 2007, An Analysis of Productivity and Technical Efficiency of Smallholder Cocoa Farmers in Nigeria, Department of Agricultural Economics and Extension, Federal University of Technology, PMB 704, Akure, 340001, Nigeria: Kamla Raj 2007: J. Soc. Sci., 15 (2): 127-133 (2007).

[2] Appadurai, A. 2002, The capacity to aspire, in V. Rao and M. Walton (eds), Culture and public action, Washington DC, The World Bank.

[3] Asiimwe, K. J. 2009, Technical efficiency of Upland Rice producers in South Western Uganda: Msc thesis: Makerere University Kampala, Uganda.

[4] Battese, G. E and T. J Coelli, 1995, A model for technical inefficiency effect in Stochastic Frontier Production for panal datall, Emperical Economics Vol 20 pp 325-345.

[5] Battese, G. E, 1992, Frontier production functions and technical efficiency: A survey of empirical applications in agricultural economics, Agricultural Economics 7 Pp. 185208.

[6] Baumol, William J. 1965, Economic Theory and Operations Analysis, 2nd ed. Englewood Cliffs NJ: Prentice-Hall.

[7] Bravo-Ureta, B. E. and A. E Pinheiro, 1997, Technical, Economic, and Allocative Efficiency in Peasant Farming: Evidence from the Dominican Republic, The Developing Economies, XXXV (1): 48-67.

[8] Bravo-Ureta, B. E., and L Rieger 1990, Alternative Production Frontier Methodologies and Dairy Farm Efficiency, Journal of Agricultural Economics 41 (2): 215-26.

[9] Eagly A. H., and S. Chaiken, 1993, The psychology of attitudes. P 186. HBJ, New York.

[10] Fairweather J. R., and N. C., Keating, 1994, Goals and management styles of New Zealand farmers, Agricultural Systems Vol. 44, pp 181-200.

[11] FAO-UN, 2011, Country STAT for sub-saharan africa: Ethiopia, Panorama Report I, PROJECT GCP/GLO/208/BMG, Food and Agriculture Organization of the United Nations Addis Ababa, May 2011.

[12] Gasson R., 1973, Goals and values of farmers, Journal of Agricultural Economics, Vol. 24 (3), pp 521-542. 
[13] Haji J., 2007, Production Efficiency of Smallholders' Vegetable-dominated Mixed Farming System in Eastern Ethiopia, A Non-Parametric Approach", Department of Economics, Swedish University of Agricultural Sciences (SLU), Uppsala, Sweden; Journal of African Economies 2007, 16 (1): 1-27; doi: 10.1093/jae/ej1044.

[14] Harwood R. R., 1979. Small Farm Development Understanding and Improving Farming Systems in the Humid Tropics. LADS Development-Oriented Literature Series.

[15] Heimeshoff M., J. Schreyögg and L. Kwietniewski, 2013, Cost and technical efficiency of physician practices: A stochastic frontier approach using panel data. Health Care Manag Sci (2014) 17: 150-161: DOI 10.1007/s10729-0139260-0: Published online: 12 December 2013: Springer Science+Business Media New York 2013.

[16] Kisaka-Lwayo M., and A. Obi, 2012, Risk Perception and Management Strategies by Small Holder Farmers in KwazuluNatal Provice, South Africa, International Management Association and institute of Agricultural Management, ISSN 2047-3710, International Journal of Agricultural Management, Volume 1 Issue 3.

[17] Lichtenstein, Sarah, and Paul Slovic, 1973, Response-Induced Reversals of Preferences in Gambling: An Extended Replication in Las Vegas, J. Experimental Psych. 101 (1973): 16-20.

[18] Maskey R., D. Lawler. and T. Batey, 2010, Goal attainment scaling: an evaluation tool to assess changes in farmers' decision making, Paper presented to the Australasian Evaluation Society International Conference held on the 1-3 September 2010, Wellington, New Zealand.

[19] Machethe, C. L., K. Mollel, K. Ayisi, M. B. Mashatola, F. D. K. Anim and F. Vanaxhe, 2004. Smallholder irrigation and agricultural development in the Olifants River 279 Basin of Limpopo Province: Management transfer, productivity, profitability and food security issues, WRC Report No 1050/1/04. Pretoria: Water Research Commission.

[20] McDonald J. 2009, Using Least Squares and Tobit in Second Stage DEA Efficiency Analyses: Flinders Business School, Flinders University, Australia. European Journal of Operational Research 20091972 792-798.

[21] Obi A. 2012, Governance structure for supply chain management in the smallholder farming systems of South Africa, InA. Obi, H. D. Van Schalkwyk, J. A. Groenewald, G. C. G. Fraser, and Aad Van Tilburg (eds), Unlocking markets to smallholders: Lesson from South Africa. Mansholt publication series-volume 10: Wageningen Academic Publishers; Netherlands.

[22] Ojo S. O., 2003, Productivity and Technical Efficiency of Poultry Egg Production in Nigeria, Department of Agricultural Economics and Extension, Federal University of Technology, P. M. B. 704, Akure, Nigeria, Asian Network for Scientific Information, International Journal of poultry Science, 2 (6): 459-464, 2003.

[23] Padilla-Fernandez M. D. and P. Nuthall, 2001, Farmers' goals and efficiency in the production of sugar cane: The Philippine case, Farm and Horticultural Management Group Lincoln University, ISSN 1174-8796, Research Report 07/2001.

[24] Phillips M. A, 2012, Inefficiency in Japanese Water Utility Firms: A Stochastic Frontier Approach: JEL Codes: L51, L95; Missouri University of Science and Technology; Economics Department, USA.

[25] Rahman, S., 2003, Profit efficiency among Bangladeshi rice farmers, Food Policy 28: 487-503.

[26] Van Kooten G. C., A. R Schoney, and K. A. Hayward, 1986, An Alternative Approach to the Evaluation of Goal Hierarchies among Farmers, Western Journal of Agricultural Economics, 11 (1): 40-49 1986 Western Agricultural Economics Association.

[27] Vimalra G., R. Singh, and K. Vijayaragavan, 2012, Correlates of Successful Agripreneurship: A Study of Awardee Farmers of Tamil Nadu". Karnataka J. Agric. Sci., 25 (2): (283-286) 2012.

[28] Wang Hung-Jen and P. Schmidt, 2002, One-Step and TwoStep Estimation of the Effects of Exogenous Variables on Technical Efficiency Levels: Journal of Productivity Analysis, 18, 129-144, 2002: JEL classification: C51, C52,D24: @ 2002 Kluwer Academic Publishers. Manufactured in The Netherlands.

[29] Water in Dry-land Collaborative Research Program (WIDCORP), 2008, Identifyingfarmer typologies, attitudes and aspirations of the Wimmera Mallee Pipeline - Supply System 6. A report prepared for the Department of Primary Industries, Horsham, December 2008, Report no. 3/08.

[30] World Food Program, 2005, Emergency Food Security Assessment Handbook, $1^{\text {st }}$ ed., Methodological guidance for better assessments, June 2005 -World Food Programme (WFP), ODAN Emergency Needs Assessment Branch. 